Check for updates

Portsmouth, UK

Cite this as: BMJ 2021;374:n1962 http://dx.doi.org/10.1136/bmj.n1962 Published: 05 August 2021

\title{
Covid-19: WHO calls for booster shot ban until end of September
}

\section{Luke Taylor}

The World Health Organization has called for a moratorium on covid-19 booster shots until the end of September to help vaccines reach poorer nations facing shortages.

Wealthier countries with widespread vaccine coverage should prioritise sending doses to those facing shortages before they start to administer extra doses to their own population, senior WHO officials said on 4 August. ${ }^{1}$

"These populations need vaccines urgently, especially health workers, older people, and other vulnerable groups," WHO director general, Tedros Adhanom Ghebreyesus, told reporters. "And yet even while hundreds of millions of people are still waiting for their first dose, some rich countries are moving towards booster doses."

Four billion vaccine doses have been administered globally, but more than $80 \%$ of them have gone to high and upper middle income countries, which make up less than half the world's population. In Africa-which saw deaths increase by $80 \%$ for the period of $19-30$ July - only $2 \%$ of people are fully vaccinated, and many healthcare workers and elderly people remain unprotected. ${ }^{2}$

"I understand the concern of all governments to protect their people from the delta variant but we cannot and we should not accept countries that have already used most of the global supply of vaccines using even more of it while the world's most vulnerable people remain unprotected,” Tedros said.

Covax, the WHO led initiative to secure affordable vaccines for poorer nations has so far delivered $\mathbf{1 8 6 . 2}$ million doses to more than 132 countries, but its deliveries have been slowed by international supply bottlenecks. 34

\section{Delta concerns}

A growing number of countries are considering rolling out booster shots because of concerns that two vaccine doses do not offer sufficient protection against the highly transmissible delta variant. Delta, which has now been detected in 132 countries, is twice as infectious as the $\alpha$ variant and is causing "breakthrough" infections in the vaccinated, according to the US Centers for Disease Control and Prevention (CDC). ${ }^{5}$

Israel announced last week that it would roll out third doses of the Pfizer vaccine to people aged over 60 . The US is also discussing rolling out extra shots. ${ }^{6}$

Though a growing number of countries are considering the need for boosters there is no scientific consensus yet that they are necessary, and they have not been approved by the US Food and Drug Administration.
"This is a big decision and it's incredibly important that we're clear about what the data is," said Kate O'Brien, WHO's director for the department of immunisation, vaccines and biologicals. "We don't have a full set of evidence around whether this is needed or not."

WHO officials said that it did not oppose boosters for vulnerable subsets of the population, such as the immunocompromised, who may not react sufficiently to two doses. It opposes vaccinating children, however, while many elderly and healthcare workers across the world remain unprotected against covid-19.

France, Israel, and the US are administering vaccines to over-12s and the UK has announced it will offer the vaccine to 16 and 17 year olds. ${ }^{7}$

Clare Wenham, associate professor of Global Health Policy at the London School of Economics, said that although donating vaccines to poorer nations is a moral obligation and is in the self-interest of richer countries, as it would help to prevent the emergence of new variants, the WHO's pleas are unlikely to have an impact.

“I don't think it's anything more than wishful thinking. There is no incentive for richer nations to do so," Wenham told The BMJ. "Richer nations want to get their electorates back to normal as soon as possible and they believe that booster shots is the way to do this."

Representative to the White House, Jen Psaki, said that the choice of rolling out booster shots or donating vaccines was a false dichotomy, and that the US "can do both" simultaneously. ${ }^{8}$

\footnotetext{
WHO. WHO press conference on coronavirus disease. 4 August 2021 www.who.int/multi-media/details/who-press-conference-on-coronavirusdisease-(covid-19)-4-august-2021.

2 WHO. WHO director-general's opening remarks at the media briefing on COVID-19. 30 July 2021. www.who.int/director-general/speeches/detail/who-director-general-s-opening-remarks-at-the-media-briefing-oncovid-19-30-july-2021

3 Unicef. Covid-19 vaccine market dashboard. www.unicef.org/supply/covid19-vaccine-market-dashboard.

4 Quartz. The biggest effort to vaccinate the developing world is falling apart. 2021. https://qz.com/2010649/covaxs-drive-to-vaccinate-the-developingworld-is-falling-apart.

5 Centers for Disease Control and Prevention. Outbreak of SARS-CoV-2 infections, including covid-19 vaccine breakthrough infections, associated with large public gatherings: Barnstable County, Massachusetts, July 2021. www.cdc.gov/mmwr/volumes/70/wr/mm7031e2.htm.

6 United States buys 200 mln more doses of Pfizer/BioNTech COVID-19 vaccine. Reuters. 2021. www.reuters.com/business/healthcare-pharmaceuticals/pfizer-says-us-govt-buying-200-mln-more-doses-covid-19-vaccine2021-07-23.

7 Mahase E. Covid-19: All 16 and 17 year olds in the UK to be offered first vaccine dose. BMJ2021;374:n1958doi: 10.1136/bmj.n1958.

8 White House. WHO moratorium on covid booster shots is a "false choice." 2021. www. youtube. com/watch? $v=$ PeslcrNe7N4.
}

This article is made freely available for use in accordance with BMJ's website terms and conditions for the duration of the covid-19 pandemic or until otherwise 
determined by BMJ. You may use, download and print the article for any lawful, non-commercial purpose (including text and data mining) provided that all copyright notices and trade marks are retained. 